\title{
ANALISIS PENANGANAN KERUSAKAN JALAN AJIBARANG- CILONGOK DENGAN METODE ASPHALT INSTITUTE
}

\section{ANALYSIS OF DAMAGE HANDLING ON THE AJIBARANG- CILONGOK ROAD USING THE ASPHALT INSTITUTE METHOD}

\author{
Sulfah Anjarwati ${ }^{1}$, Tita Ria Pristianita ${ }^{2}$ \\ ${ }^{12}$ Program Studi S1 Teknik Sipil, Fakultas Teknik dan Sains \\ Universitas Muhammadiyah Purwokerto
}

\section{Informasi Artikel}

Dikirim,

Direvisi,

Diterima,

\section{Korespondensi Penulis:}

Sulfah Anjarwati

Program Studi Teknik Sipil Universitas Muhammadiyah Purwokerto

JL. K.H. Ahmad Dahlan

Purwokerto, 53182

Email:

sulfahanjarwati75@gmail.com

\section{ABSTRAK}

Penelitian kondisi perkerasan jalan merupakan salah satu tahapan untuk menentukan jenis program evaluasi yang perlu dilakukan. Penelitian ini bertujuan untuk mengetahui nilai kondisi perkerasan ruas Jalan Ajibarang - Cilongok dengan panjang ruas jalan 6 $\mathrm{km}$ dan lebar jalan $7 \mathrm{~m}$. Dalam penelitian ini menggunakan data sekunder yang diambil pada penelitian sebelumnya Penilaian kondisi perkerasan jalan salah satunya dengan menggunakan metode Asphalt Institute. Urutan nilai kondisi pemeliharaan jalan metode Asphalt Institute didasarkan pada rentang nilai 0 sampai 100. Dari hasil analisa kerusakan pada ruas Jalan Ajibarang - Cilongok dengan metode Asphalt Institute didapatkan nilai rata - rata kondisi jalan 93,1 yang dimasukan pada program pemeliharaan rutin.

Kata Kunci : Kerusakan Jalan, Asphalt Institute

\section{ABSTRACT}

Research on pavement conditions is one of the steps to determine the type of evaluation program that needs to be carried out. This study aims to determine the value of the pavement conditions of Jalan Ajibarang - Cilongok with a road length of $6 \mathrm{~km}$ and a road width of $7 \mathrm{~m}$. In this study using secondary data taken in previous studies. One of the assessment of road pavement conditions is by using the Asphalt Institute method. The order of the road maintenance conditions by the Asphalt Institute method is based on a value range of 0 to 100 . From the results of the analysis of damage to Jalan Ajibarang - Cilongok using the Asphalt Institute method, the average value of road conditions is 93.1 which is included in the routine maintenance program.

Keyword : Road Damage, Asphalt Institute 


\section{PENDAHULUAN}

Kerusakan jalan yang terjadi di berbagai daerah khususnya pada ruas jalan Ajibarang - Cilongok Kabupaten Banyumas Jawa Tengah merupakan salah satu jalan alternatif untuk kendaraan berat, dengan kondisi perkerasan flexible pavement. Permasalahan yang serius pada jalan Ajibarang - Cilongok disebabkan banyak sekali jenis kerusakan pada jalan tersebut. Ruas jalan Ajibarang - Cilongok juga sering terjadi kemacetan karena padatnya kendaraan yang melintas. Kerugian yang diderita pengguna jalan akibat kerusakan jalan tersebut seperti kecelakaan lalu lintas, waktu tempuh lama, kemacetan dan lain - lain.

Untuk mengetahui kondisi kerusakan jalan dengan menganalisis kerusakan yang terjadi salah satunya dengan menggunakan metode Asphalt Institute. Metode Asphalt Institute merupakan salah satu solusi untuk menyelesaikan dan mencari cara penanganan pada permasalahan kerusakan jalan. Metode ini merupakan sistem penilaian kondisi perkerasan jalan berdasarkan jenis, tingkat, dan luas kerusakan yang terjadi dan dapat digunakan sebagai acuan dalam usaha pemeliharaan yang ada di jalan Ajibarang - Cilongok, sehingga bisa diperoleh penanganan yang akan di lakukan.

\section{METODE PENELITIAN}

Penelitian dilakukan pada ruas jalan Ajibarang - Cilongok, Kabupaten Banyumas, Provinsi Jawa Tengah. Pada ruas jalan Nasional sepanjang $6 \mathrm{~km}$ dan lebar perkerasan $7 \mathrm{~m}$. Pada metode Asphalt Institute, data yang diperoleh dari survey adalah data evaluasi kondisi perkerasan dan nilai kerusakan perkerasan berdasarkan masing - masing jenis kerusakan yang terdapat di lapangan. Dalam sistem penilaian menurut Asphalt Institute, sistem penilaiannya disebut Pavement Condition Rating (PCR). Nilai PCR $(0-100)$ diperoleh dengan mengurangi nilai 100 dengan jumlah nilai kerusakannya. Penilain menurut Asphalt Institute adalah sebagai berikut :

1. Evaluasi Kondisi Perkerasan

Pengisian formulir evaluasi kondisi perkerasan dilakukan dengan memberikan tanda ceklis pada kolom keparahan kerusakan. Selanjutnya dilakukan pemberian presentase dan nilai terhadap keparahan kerusakan dan karakteristik kerusaka.

2. Penilaian Perkerasan Aspal

Memberikan nilai kerusakan pada formulir nilai kondisi yang ditentukan berdasarkan pertimbangan hasil evaluasi kondisi permukaan dan tingkat parahnya kerusakan yang diamati.

3. Menghitung Nilai Kondisi

Dengan menggunakan sistem penilaian, kerusakan yang kurang serius akibatnya bagi perkerasan diberikan nilai $0-5$. Kerusakan yang sifatnya lebih serius, yaitu kerusakan yang secara langsung mempengaruhi kekuatan perkerasan, diberi nilai $0-10$.

Nilai Kondisi $=100-$ Jumlah Nilai Kerusakan

4. Interpretasi Nilai Kondisi

Nilai kondisi antara 80 - 100, diperlukan pemeliharaan normal. Nilai kondisi di bawah 80 diperlukan pelapisan tambahan (overlay). Dan jika nilai kondisi dibawah 30, maka diperlukan pembangunan kembali (rekontruksi )

\section{HASIL DAN PEMBAHASAN}

Hasil Analisis Metode Asphalt Institute dapat dilihat pada tabel 1. berikut :

Tabel 1. Rekapitulasi Penetapan Kondisi Jalan metode Asphalt Institute

\begin{tabular}{crcc}
\hline No & Stationing & Nilai Kondisi & $\begin{array}{c}\text { Urutan Prioritas Menentukan } \\
\text { Perbaikan Jalan }\end{array}$ \\
\hline 1 & $34+590-34+490$ & 93 & Pemeliharaan Rutin \\
2 & $34+490-34+390$ & 92 & Pemeliharaan Rutin \\
3 & $34+390-34+290$ & 88 & Pemeliharaan Rutin \\
4 & $34+290-34+190$ & 91 & Pemeliharaan Rutin \\
5 & $34+190-34+090$ & 90 & Pemeliharaan Rutin \\
6 & $34+090-33+990$ & 92 & Pemeliharaan Rutin \\
7 & $33+990-33+890$ & 92 & Pemeliharaan Rutin \\
8 & $33+890-33+790$ & 95 & Pemeliharaan Rutin \\
9 & $33+790-33+690$ & 95 & Pemeliharaan Rutin \\
10 & $33+690-33+590$ & 93 & Pemeliharaan Rutin \\
11 & $33+590-33+490$ & 95 & Pemeliharaan Rutin \\
12 & $33+490-33+390$ & 95 & Pemeliharaan Rutin \\
13 & $33+390-33+290$ & 95 & Pemeliharaan Rutin \\
\hline
\end{tabular}

CIVeng Vol.1, No.2, Juli $2020: 49 \sim 54$ 


\begin{tabular}{|c|c|c|c|}
\hline No & Stationing & Nilai Kondisi & $\begin{array}{c}\text { Urutan Prioritas Menentukan } \\
\text { Perbaikan Jalan }\end{array}$ \\
\hline 14 & $33+290-33+190$ & 95 & Pemeliharaan Rutin \\
\hline 15 & $33+190-33+090$ & 95 & Pemeliharaan Rutin \\
\hline 16 & $33+090-32+990$ & 95 & Pemeliharaan Rutin \\
\hline 17 & $32+990-32+890$ & 95 & Pemeliharaan Rutin \\
\hline 18 & $32+890-32+790$ & 95 & Pemeliharaan Rutin \\
\hline 19 & $32+790-32+690$ & 95 & Pemeliharaan Rutin \\
\hline 20 & $32+690-32+590$ & 95 & Pemeliharaan Rutin \\
\hline 21 & $32+590-32+490$ & 94 & Pemeliharaan Rutin \\
\hline 22 & $32+490-32+390$ & 87 & Pemeliharaan Rutin \\
\hline 23 & $32+390-32+290$ & 95 & Pemeliharaan Rutin \\
\hline 24 & $32+290-32+190$ & 93 & Pemeliharaan Rutin \\
\hline 25 & $32+190-32+090$ & 93 & Pemeliharaan Rutin \\
\hline 26 & $32+090-31+990$ & 93 & Pemeliharaan Rutin \\
\hline 27 & $31+990-31+890$ & 88 & Pemeliharaan Rutin \\
\hline 28 & $31+890-31+790$ & 91 & Pemeliharaan Rutin \\
\hline 29 & $31+790-31+690$ & 93 & Pemeliharaan Rutin \\
\hline 30 & $31+690-31+590$ & 94 & Pemeliharaan Rutin \\
\hline 31 & $31+590-31+490$ & 93 & Pemeliharaan Rutin \\
\hline 32 & $31+490-31+390$ & 95 & Pemeliharaan Rutin \\
\hline 33 & $31+390-31+290$ & 92 & Pemeliharaan Rutin \\
\hline 34 & $31+290-31+190$ & 91 & Pemeliharaan Rutin \\
\hline 35 & $31+190-31+090$ & 94 & Pemeliharaan Rutin \\
\hline 36 & $31+090-30+990$ & 94 & Pemeliharaan Rutin \\
\hline 37 & $30+990-31+890$ & 94 & Pemeliharaan Rutin \\
\hline 38 & $30+890-30+790$ & 95 & Pemeliharaan Rutin \\
\hline 39 & $30+790-30+690$ & 94 & Pemeliharaan Rutin \\
\hline 40 & $30+690-30+590$ & 93 & Pemeliharaan Rutin \\
\hline 41 & $30+590-30+490$ & 94 & Pemeliharaan Rutin \\
\hline 42 & $30+490-30+390$ & 92 & Pemeliharaan Rutin \\
\hline 43 & $30+390-30+290$ & 89 & Pemeliharaan Rutin \\
\hline 44 & $30+290-30+190$ & 90 & Pemeliharaan Rutin \\
\hline 45 & $30+190-30+090$ & 92 & Pemeliharaan Rutin \\
\hline 46 & $30+090-29+990$ & 91 & Pemeliharaan Rutin \\
\hline 47 & $29+990-29+890$ & 93 & Pemeliharaan Rutin \\
\hline 48 & $29+890-29+790$ & 95 & Pemeliharaan Rutin \\
\hline 49 & $29+790-29+690$ & 94 & Pemeliharaan Rutin \\
\hline 50 & $29+690-29+590$ & 93 & Pemeliharaan Rutin \\
\hline 51 & $29+590-29+490$ & 94 & Pemeliharaan Rutin \\
\hline 52 & $29+490-29+390$ & 93 & Pemeliharaan Rutin \\
\hline 53 & $29+390-29+290$ & 95 & Pemeliharaan Rutin \\
\hline 54 & $29+290-29+190$ & 92 & Pemeliharaan Rutin \\
\hline 55 & $29+190-29+090$ & 94 & Pemeliharaan Rutin \\
\hline 56 & $29+090-28+990$ & 94 & Pemeliharaan Rutin \\
\hline 57 & $28+990-28+890$ & 91 & Pemeliharaan Rutin \\
\hline 58 & $28+890-28+790$ & 95 & Pemeliharaan Rutin \\
\hline 59 & $28+790-28+690$ & 95 & Pemeliharaan Rutin \\
\hline 60 & $28+690-28+590$ & 93 & Pemeliharaan Rutin \\
\hline \multicolumn{2}{|c|}{ Nilai Rata - Rata Kondisi Jalan } & 93,1 & Pemeliharan Rutin \\
\hline
\end{tabular}

Hasil Penanganan Kerusakan Jalan

Hasil penanganan kerusakan yang dapat dilakukan dapat dilihat pada Tabel 2.

Tabel 2. Penanganan Kerusakan Jalan

\begin{tabular}{ccclc}
\hline No & Stationing & Jenis Pemeliharaan & \multicolumn{1}{c}{ Jenis Kerusakan } & Penanganan \\
\hline \multirow{2}{*}{1} & \multirow{2}{*}{$34+590-34+490$} & P. Rutin & R. Kulit Buaya $>2 \mathrm{~mm}$ & P5 \\
& & & Tambalan & P5
\end{tabular}




\begin{tabular}{|c|c|c|c|c|}
\hline No & Stationing & Jenis Pemeliharaan & Jenis Kerusakan & Penanganan \\
\hline \multirow{2}{*}{2} & \multirow{2}{*}{$34+490-34+390$} & \multirow{2}{*}{ P. Rutin } & Agregat Licin & $\mathrm{P} 2$ \\
\hline & & & Tambalan & P5 \\
\hline \multirow{5}{*}{3} & \multirow{5}{*}{$34+390-34+290$} & \multirow{5}{*}{ P. Rutin } & R. Kulit Buaya, > $2 \mathrm{~mm}$ & P5 \\
\hline & & & R. Memanjang, $>2$ mm & P4 \\
\hline & & & Lubang Kedalaman $>50 \mathrm{~mm}$ & P5 \\
\hline & & & Agregat Licin & $\mathrm{P} 2$ \\
\hline & & & Tambalan & P5 \\
\hline \multirow{3}{*}{4} & \multirow{3}{*}{$34+290-34+190$} & \multirow{3}{*}{ P. Rutin } & Agregat Licin & $\mathrm{P} 2$ \\
\hline & & & P. Butiran & $\mathrm{P} 2$ \\
\hline & & & Tambalan & P5 \\
\hline \multirow{5}{*}{5} & \multirow{5}{*}{$34+190-34+090$} & \multirow{5}{*}{ P. Rutin } & Agregat Licin & $\mathrm{P} 2$ \\
\hline & & & Lubang, Kedalaman $<50 \mathrm{~mm}$ & P6 \\
\hline & & & R. Memanjang, $>2 \mathrm{~mm}$ & P4 \\
\hline & & & R.Blok & $\mathrm{P} 4$ \\
\hline & & & Tambalan & P5 \\
\hline \multirow{3}{*}{6} & \multirow{3}{*}{$34+090-33+990$} & \multirow{3}{*}{ P. Rutin } & P. Butiran & $\mathrm{P} 2$ \\
\hline & & & R. Kulit Buaya, $>2 \mathrm{~mm}$ & P5 \\
\hline & & & Tambalan & P5 \\
\hline \multirow{4}{*}{7} & \multirow{4}{*}{$33+990-33+890$} & \multirow{4}{*}{ P. Rutin } & R. Memanjang, $>2 \mathrm{~mm}$ & P4 \\
\hline & & & R. Kulit Buaya, $>2 \mathrm{~mm}$ & P5 \\
\hline & & & R. Blok & P4 \\
\hline & & & Tambalan & P5 \\
\hline 8 & $33+890-33+790$ & P. Rutin & Tambalan & P5 \\
\hline 9 & $33+790-33+690$ & P. Rutin & Tidak ada & - \\
\hline & & & R. Memanjang, $>2 \mathrm{~mm}$ & $\mathrm{P} 4$ \\
\hline 10 & $33+690-33+590$ & P. Rutin & R. Kulit Buaya, > $2 \mathrm{~mm}$ & P5 \\
\hline 11 & $33+590-33+490$ & P. Rutin & Tambalan & P5 \\
\hline 12 & $33+490-33+390$ & P. Rutin & Tambalan & P5 \\
\hline 13 & $33+390-33+290$ & P. Rutin & Tambalan & P5 \\
\hline 14 & $33+290-33+190$ & P. Rutin & 0 & - \\
\hline 15 & $33+190-33+090$ & P. Rutin & Tambalan & P5 \\
\hline 16 & $33+090-32+990$ & P. Rutin & 0 & - \\
\hline 17 & $32+990-32+890$ & P. Rutin & 0 & - \\
\hline 18 & $32+890-32+790$ & P. Rutin & 0 & - \\
\hline 19 & $32+790-32+690$ & P. Rutin & 0 & - \\
\hline 20 & $32+690-32+590$ & P. Rutin & 0 & - \\
\hline & & & R. Kulit Buaya, > 2 mm & P5 \\
\hline 21 & $32+590-32+490$ & P. Rutin & Tambalan & P5 \\
\hline & & & Lubang, Kedalaman $<50 \mathrm{~mm}$ & P6 \\
\hline & & & R. Kulit Buaya, > $2 \mathrm{~mm}$ & P5 \\
\hline & & & Sungkur & P5 \\
\hline 22 & $32+490-32+390$ & P. Rutin & P. Butiran & $\mathrm{P} 2$ \\
\hline & & & R. Memanjang, $>2 \mathrm{~mm}$ & P4 \\
\hline & & & Tambalan & P5 \\
\hline 23 & $32+390-32+290$ & P. Rutin & Tambalan & P5 \\
\hline & & & R. Memanjang, > $2 \mathrm{~mm}$ & P4 \\
\hline 24 & $32+290-32+190$ & P. Rutin & R. Blok & P4 \\
\hline & & & Tambalan & P5 \\
\hline & & & Agregat Licin & $\mathrm{P} 2$ \\
\hline 25 & $32+190-32+090$ & P. Rutin & R. Kulit Buaya, > $2 \mathrm{~mm}$ & P5 \\
\hline & & & Tambalan & P5 \\
\hline & & & Agregat Licin & $\mathrm{P} 2$ \\
\hline 26 & $32+090-31+990$ & P. Rutin & Tambalan & P5 \\
\hline & & & Agregat Licin & $\mathrm{P} 2$ \\
\hline & & & Sungkur & P5 \\
\hline 27 & $31+990-31+890$ & P. Rutin & R. Kulit Buaya, > $2 \mathrm{~mm}$ & P5 \\
\hline & & & R. Melintang & P4 \\
\hline
\end{tabular}




\begin{tabular}{|c|c|c|c|c|}
\hline No & Stationing & Jenis Pemeliharaan & Jenis Kerusakan & Penanganan \\
\hline \multirow{6}{*}{28} & \multirow{6}{*}{$31+890-31+790$} & \multirow{6}{*}{ P. Rutin } & Tambalan & P5 \\
\hline & & & R. Kulit Buaya, > 2 mm & P5 \\
\hline & & & R. Memanjang, $>2 \mathrm{~mm}$ & P4 \\
\hline & & & Lubang, Kedalaman $<50 \mathrm{~mm}$ & P6 \\
\hline & & & Tambalan & P5 \\
\hline & & & Lubang, Kedalaman $<50 \mathrm{~mm}$ & P6 \\
\hline \multirow[t]{2}{*}{29} & \multirow[t]{2}{*}{$31+790-31+690$} & \multirow[t]{2}{*}{ P. Rutin } & R. Kulit Buaya, > 2 mm & P5 \\
\hline & & & Tambalan & P5 \\
\hline \multirow{3}{*}{30} & \multirow{2}{*}{$31+690-31+590$} & \multirow{3}{*}{ P. Rutin } & R. Kulit Buaya, > 2 mm & P5 \\
\hline & & & Tambalan & P5 \\
\hline & \multirow{3}{*}{$31+590-31+490$} & & R. Kulit Buaya, > 2 mm & P5 \\
\hline \multirow[t]{2}{*}{31} & & \multirow[t]{2}{*}{ P. Rutin } & Lubang, Kedalaman $<50 \mathrm{~mm}$ & P6 \\
\hline & & & Tambalan & P5 \\
\hline \multirow[t]{2}{*}{32} & \multirow[t]{2}{*}{$31+490-31+390$} & \multirow[t]{2}{*}{ P. Rutin } & Tambalan & P5 \\
\hline & & & Lubang, Kedalaman $<50 \mathrm{~mm}$ & P6 \\
\hline \multirow[t]{3}{*}{33} & \multirow[t]{2}{*}{$31+390-31+290$} & \multirow[t]{2}{*}{ P. Rutin } & R. Kulit Buaya, $>2$ mm & P6 \\
\hline & & & Agregat Licin & $\mathrm{P} 2$ \\
\hline & & & Agregat Licin & $\mathrm{P} 2$ \\
\hline 34 & $31+290-31+190$ & P Rutin 1 ( & R. Kulit Buaya, > 2 mm & P5 \\
\hline 34 & $31+290-31+190$ & P. Kutin & Sungkur & P5 \\
\hline & & & Tambalan & P5 \\
\hline 35 & $31+190-31+090$ & P Rutin & R. Kulit Buaya, > 2 mm & P5 \\
\hline 35 & $31+190-31+090$ & P. Kuttn & Tambalan & P5 \\
\hline 26 & $21,000-20,000$ & D D pit & R. Memanjang, $>2 \mathrm{~mm}$ & P4 \\
\hline 36 & $31+090-30+990$ & P. Kutin & Tambalan & P5 \\
\hline & & & R. Memanjang, $>2 \mathrm{~mm}$ & P4 \\
\hline 37 & $30+990-31+890$ & P. Rutin & Tambalan & P5 \\
\hline 38 & $30+890-30+790$ & P. Rutin & Tambalan & P5 \\
\hline & & & Lubang, Kedalaman $<50 \mathrm{~mm}$ & P6 \\
\hline 39 & $30+790-30+690$ & P. Rutin & Tambalan & P5 \\
\hline & & & Agregat Licin & $\mathrm{P} 2$ \\
\hline 40 & $30+690-30+590$ & P. Rutin & Lubang, Kedalaman $<50 \mathrm{~mm}$ & P6 \\
\hline & & & Tambalan & P5 \\
\hline 41 & $30+500-30+490$ & P Rutin 1 ( & Sungkur & P5 \\
\hline 41 & $30+590-30+490$ & P. Rutın & Tambalan & P5 \\
\hline & & & R. Kulit Buaya, > 2 mm & P5 \\
\hline 42 & $30+490-30+390$ & P. Rutin & Lubang, Kedalaman $<50 \mathrm{~mm}$ & P6 \\
\hline & & & Tambalan & P5 \\
\hline & & & R. Memanjang, $>2 \mathrm{~mm}$ & P4 \\
\hline & & & R. Kulit Buaya, > 2 mm & P5 \\
\hline & & & R. Melintang & P4 \\
\hline 43 & $30+390-30+290$ & P. Rutin & Agregat Licin & $\mathrm{P} 2$ \\
\hline & & & Lubang, Kedalaman $<50 \mathrm{~mm}$ & P6 \\
\hline & & & Tambalan & P5 \\
\hline & & & R. Melintang & P4 \\
\hline & & & R. Kulit Buaya, > 2 mm & P5 \\
\hline 44 & $30+290-30+190$ & P. Rutin & R.Blok & $\mathrm{P} 4$ \\
\hline & & & Alur & P6 \\
\hline & & & Agregat Licin & $\mathrm{P} 2$ \\
\hline 45 & $30+190-30+090$ & P. Rutin & R. Kulit Buaya, > $2 \mathrm{~mm}$ & P5 \\
\hline & & & Tambalan & P5 \\
\hline & & & R. Kulit Buaya, > 2 mm & P5 \\
\hline & & & Agregat Licin & $\mathrm{P} 2$ \\
\hline 46 & $30+090-29+990$ & P. Rutin & Lubang, Kedalaman $<50 \mathrm{~mm}$ & P6 \\
\hline & & & Tambalan & P5 \\
\hline 47 & $29+990-29+890$ & P Rutin & R. Kulit Buaya, > 2 mm & P5 \\
\hline 47 & $29+990-29+890$ & P. Rutın & Tambalan & P5 \\
\hline
\end{tabular}




\begin{tabular}{|c|c|c|c|c|}
\hline No & Stationing & Jenis Pemeliharaan & Jenis Kerusakan & Penanganan \\
\hline 48 & $29+890-29+790$ & P. Rutin & 0 & - \\
\hline \multirow{2}{*}{49} & \multirow{2}{*}{$29+790-29+690$} & \multirow{2}{*}{ P. Rutin } & Lubang, Kedalaman $<50 \mathrm{~mm}$ & P6 \\
\hline & & & Tambalan & P5 \\
\hline \multirow{2}{*}{50} & \multirow{2}{*}{$29+690-29+590$} & \multirow{2}{*}{ P. Rutin } & R. Kulit Buaya, > $2 \mathrm{~mm}$ & P5 \\
\hline & & & Tambalan & P5 \\
\hline \multirow{2}{*}{51} & \multirow{2}{*}{$29+590-29+490$} & \multirow{2}{*}{ P. Rutin } & Agregat Licin & $\mathrm{P} 2$ \\
\hline & & & Tambalan & P5 \\
\hline \multirow{2}{*}{52} & \multirow{2}{*}{$29+490-29+390$} & \multirow{2}{*}{ P. Rutin } & R. Memanjang, > $2 \mathrm{~mm}$ & P4 \\
\hline & & & Tambalan & P5 \\
\hline \multirow[t]{2}{*}{53} & \multirow[t]{2}{*}{$29+390-29+290$} & \multirow[t]{2}{*}{ P. Rutin } & Tambalan & P5 \\
\hline & & & Agregat Licin & P2 \\
\hline \multirow[t]{2}{*}{54} & \multirow[t]{2}{*}{$29+290-29+190$} & \multirow[t]{2}{*}{ P. Rutin } & R. Memanjang, > $2 \mathrm{~mm}$ & P4 \\
\hline & & & Tambalan & P5 \\
\hline \multirow{2}{*}{55} & \multirow{2}{*}{$29+190-29+090$} & \multirow{2}{*}{ P. Rutin } & R. Memanjang, > $2 \mathrm{~mm}$ & P4 \\
\hline & & & Tambalan & P5 \\
\hline \multirow{3}{*}{56} & \multirow{2}{*}{$29+090-28+990$} & \multirow{2}{*}{ P. Rutin } & R. Kulit Buaya, > 2 mm & P5 \\
\hline & & & Tambalan & P5 \\
\hline & \multirow{4}{*}{$28+990-28+890$} & \multirow{4}{*}{ P. Rutin } & R. Kulit Buaya, > $2 \mathrm{~mm}$ & P5 \\
\hline \multirow{3}{*}{57} & & & R. Memanjang, > $2 \mathrm{~mm}$ & P4 \\
\hline & & & Agregat Licin & $\mathrm{P} 2$ \\
\hline & & & Tambalan & P5 \\
\hline 58 & $28+890-28+790$ & P. Rutin & 0 & - \\
\hline 59 & $28+790-28+690$ & P. Rutin & Tambalan & P5 \\
\hline 60 & $28+690-28+590$ & P. Rutin & R. Kulit Buaya, > $2 \mathrm{~mm}$ & P5 \\
\hline
\end{tabular}

\section{KESIMPULAN}

- Hasil analisis pada ruas jalan Ajibarang - Cilongok menggunakan metode Asphalt Institute didapat nilai rata-rata kondisi jalan sebesar 93,1 dalam penanganannya termasuk dalam program pemeliharaan rutin.

- Pada ruas jalan Ajibarang - Cilongok penanganan kerusakan permukaan jalan pada lapis perkerasan lentur dilakukan berdasarkan Metode Perbaikan Standar Bina Marga 2011. Mengklasifikasikan metode perbaikan standar untuk kerusakan jalan menjadi 6 macam diantaranya yaitu P1 : penebaran pasir, P2 : pengaspalan, P3 : menutup retakan, P4 : mengisi retakan, P5 : penambalan lubang, P6 : perataan.

\section{DAFTAR PUSTAKA}

[1] Gilang, R. and Prasetyanto, D. (2015) Perbandingan Nilai Kondisi Permukaan Perkerasan Jalan Lentur Dengan Menggunakan Asphalt Institute dan Pavement Condition Index (PCI). Malang. Fakultas Teknik, Institute Teknologi Nasional Malang

[2] Herbin, F. B. and Jeni, P. (2019) Analisa Kerusakan Jalan Menggunakan Metode Pavement Condition Index (PCI) dan Asphalt Institute $M S$ - 17. Merauke. Fakultas Teknik, Universitas Musamus

[3] Hardiyatno, H. C. (2009) Pemeliharaan Jalan Raya. Yogyakarta: Gadjah Mada University

[4] Ida, A. A. A, Sakti, A. A, Isran, R. and Sumarni, H. (2018) Evaluating The Road Damage Of Flexible Pavement Using Digital Image: an Internasional Journal, 10(2), pp. 24 - 27. doi: https://doi.org/10.30880/ijie.2018.10.02.005

[5] Ulfi, J. (2018) Analisa Tingkat Kerusakan Pada Perkerasan Jalan (Studi Kasus Jalan Lingkar Barat Kecamatan Kerinci Kabupaten Pelalawan Provinsi Riau). Pekanbaru. Sekolah Tinggi Teknologi Pekanbaru 